\title{
Performance and Emission Analysis of Diesel Engine Using Oxygenated compounds
}

\author{
Sateesh Yalavarthi ${ }^{1}$, Anil Kumar.Chintalapudi ${ }^{2}$ and Satya Dev ${ }^{3}$ \\ ${ }^{1,2,3}$ Department of Mechanical Engineering, DVR\&DR.HS MIC College of \\ Technology, Kanchikacherla, Krishna (DT),Andhra Pradesh, India
}

\begin{abstract}
The addition of oxygenated compounds to diesel, supply additional oxygen which results in more burning of the fuel and thereby reducing emissions. In the present study, two oxygenated compounds, such as Ethoxy ethanol and Ethylene glycol are considered on a $3.7 \mathrm{KW}$, water cooled, and kirloskar engine. The selected oxygenated compounds are blended with diesel fuel in proportions of $5 \%$ and $10 \%$ by volume and the experimental study is conducted to evaluate the performance and emissions of the diesel engine. The data obtained is compared with the conventional diesel fuel and the results reveal that Brake Thermal Efficiency (BTE) decreased with increase in the blend percentage. $\mathrm{CO}_{2}$, $H C$ emissions decreased while $N O_{X}$ emissions increased.
\end{abstract}

Keywords: Biodiesel, Emissions, Performance, Ethylene Glycol, Ethoxy Ethanol Blends

\section{Introduction}

Majority of the world's energy needs are supplied through petro-chemical sources, coal and natural gases, with the exception of hydro-electricity and nuclear energy, all these sources are finite and as current usage rates will be consumed shortly. Out of these diesel fuels have an essential function in the industrial transports and agricultural goods due to its low cost and high thermal efficiency. Fossil fuels are the largest producer of $\mathrm{CO}_{2}$ emissions and the significant use of fossil fuels is thickening the $\mathrm{CO}_{2}$ blanket over the Earth. This blanket traps ultra-violet (UV) rays (which are essentially heat) that have been originally received by the Earth from the Sun. As the world is becoming more advanced in technology more energy is being used to keep up with the changing requirements. It is essential to improve the efficiency with the usage of natural resources, and develop renewable alternatives wherever possible to protect resources on which the current and future generations depend. The diesel industry is under increasing pressure worldwide to find methods to reduce particulate matter, $\mathrm{NO}_{\mathrm{x}}$, smoke, $\mathrm{HC}$ and $\mathrm{CO}$ emissions. Approaches considered include engine modifications, fuel changes and exhaust after treatment methods. It is here where oxygenated diesel blends come into the picture as it is found that the use of these blends reduce the emissions considerably without affecting the efficiency of the engine used. Oxygenated diesel blends provide an effective way to reduce emissions from diesel engines, particularly smoke. Smoke or particulate matter emissions are mainly due to the lack of oxygen during the combustion process. $[1,2,8]$ In addition to that a slight increase of bsfc is observed due to the slight decrease of fuel heating value with the increase of the oxygen content Brake thermal efficiency increased when the oxygen content was increased. [4]When taking into consideration the production potential of bio-diesel brake specific fuel consumption and $\mathrm{NO}_{\mathrm{x}}$ emissions the ratio of the biodiesel in the bio-diesel-diesel fuel blend should be kept at low ratio. [3] Relative to diesel fuel, SFC for blended fuel did not increase significantly at higher engine speeds. Diesel fuel contains no oxygen in its molecular structure. [5, 6] The only oxygen available for combustion is from the air taken during the suction process. Since oxygenated 
compounds contain oxygen and faster evaporation, this will provide additional oxygen resulting in better combustion and reduced emissions. [7] Because of the lower energy density of the blends, it is necessary to increase the mass of the delivery blends to gain same power.

Oxygenated compounds are those compounds which contain oxygen as a predominant element. This project intends to show that the use of oxygenates in diesel fuel in small percentages can reduce the harmful emissions like $\mathrm{HC}, \mathrm{NO}_{\mathrm{X}}, \mathrm{CO}_{2}$ etc., without drastically decreasing the efficiency of the diesel engine.

\section{Test Fuels}

For our experimentation two oxygenated compounds have been selected. Ethoxy ethanol and Ethylene glycol are used in this study. Blending of oxygenated compounds with pure diesel is done with care according to proportion and the proportions are 5\%, $10 \%$ of ethoxy ethanol and ethylene glycol are mixed with diesel fuel by volume. The fuel properties of diesel, Ethoxy ethanol and Ethylene glycol are shown in the Table 1.

Table 1. Fuel Properties

\begin{tabular}{|l|l|l|l|}
\hline Properties & Diesel & Ethylene Glycol & Ethoxy Ethanol \\
\hline Boiling point & $282-338^{\circ} \mathrm{C}$ & $197.3^{\circ} \mathrm{C}$ & $135^{\circ} \mathrm{C}$ \\
\hline Melting point & $254-285^{\circ} \mathrm{C}$ & $-12.9^{\circ} \mathrm{C}$ & $-70^{\circ} \mathrm{C}$ \\
\hline Cetane number & $40-55$ & $55-60$ & $50-55$ \\
\hline Flash point & $52^{\circ} \mathrm{C}$ & $111^{\circ} \mathrm{C}$ & $44^{\circ} \mathrm{C}$ \\
\hline Density $\left(\mathrm{g} / \mathrm{cm}^{3}\right)$ & $0.87-0.95$ & 1.11 & 0.93 \\
\hline Viscosity $\left(\mathrm{Cst}, 40^{\circ} \mathrm{C}\right)$ & 4.2 & 2.62 & 2.45 \\
\hline
\end{tabular}

Table 2. Fuel Blend Properties of Ethylene Glycol and Ethoxy Ethanol

\begin{tabular}{|l|l|l|l|l|}
\hline \multirow{2}{*}{ Properties } & \multicolumn{2}{|l|}{ Ethylene Glycol Blends } & \multicolumn{2}{l|}{ Ethoxy Ethanol Blends } \\
\cline { 2 - 5 } & $\mathbf{5 \%}$ & $\mathbf{1 0 \%}$ & $\mathbf{5 \%}$ & $\mathbf{1 0 \%}$ \\
\hline Boiling point & $136^{\circ} \mathrm{C}-$ & $146^{\circ} \mathrm{C}-370^{\circ} \mathrm{C}$ & $171^{\circ} \mathrm{C}-370^{\circ} \mathrm{C}$ & $120^{\circ} \mathrm{C}-370^{\circ} \mathrm{C}$ \\
& $370^{\circ} \mathrm{C}$ & & & \\
\hline Flash point & $46^{\circ} \mathrm{C}$ & $48^{\circ} \mathrm{C}$ & $39^{\circ} \mathrm{C}$ & $38^{\circ} \mathrm{C}$ \\
\hline Fire point & $52^{\circ} \mathrm{C}$ & $62^{\circ} \mathrm{C}$ & $50^{\circ} \mathrm{C}$ & $52^{\circ} \mathrm{C}$ \\
\hline Cetane number & 58 & 64 & 53 & 62 \\
\hline GrossC.V $(\mathrm{kcals} / \mathrm{kg})$ & 10536 & 10875 & 10525 & 9661 \\
\hline Dencity30 $30^{\circ} \mathrm{C}(\mathrm{g} / \mathrm{cc})$ & 08207 & 0.8197 & 0.8306 & 0.8246 \\
\hline Viscosity $\left(\mathrm{Cst}, 40^{\circ} \mathrm{C}\right)$ & 2.74 & 2.73 & 2.36 & 2.54 \\
\hline
\end{tabular}

\section{Experimental Setup}

Experimental setup consisting of four stroke single cylinder diesel engine with mechanical brake drum fixed to the engine fly wheel was selected for the study. A separate panel board is used to fix burette with stop cock performance analysis is, to fill up the identified diesel fuel blend into the fuel tank mounted on the panel frame. the engine is started the engine and allowed it to stabilize at rated speed(1500rpm). Now load the engine in steps of quarter, half, three fourth and full load and allow the engine to stabilize at each load. Record all the required parameters indicated on the digital indicators which are mounted on the panel board like, speed of the engine from digital $\mathrm{rpm}$ indicator, load from the spring balance, fuel consumption from burette, quantity of airflow from manometer. In addition to this, exhaust gas is sent into exhaust gas analyzer 
for the analysis of emissions present particular diesel fuel blend. Sct-g-5 multi gas analyzer ( 5 gases) is based on infrared spectrometry technology with signal inputs from an electrochemical cell. Non-dispersive infrared measurement techniques are used for CO, $\mathrm{CO}_{2}, \mathrm{O}_{2}$ and $\mathrm{HC}$ gases. Load the engine step by step and note down corresponding parameters. Turn off the fuel knob provided on the panel after the test. The experimental setup is shown in Figure 1, gas analyzer in Figure 2, and Specifications of the experimental engine and gas analyzer is shown in Table 3 and Table 4.

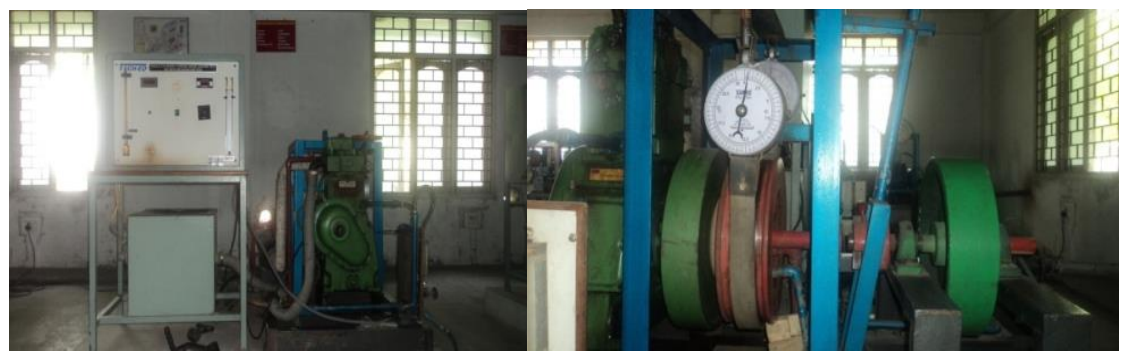

Figure 1. Four Stroke Diesel Engine

Table 3. Specifications of the Experimental Engine

\begin{tabular}{|l|l|}
\hline Engine type & Vertical, 4-stroke,constant speed, DI engine \\
\hline Compression ratio & $16.5: 1$ \\
\hline Bore & $80 \mathrm{~mm}$ \\
\hline Stroke & $110 \mathrm{~mm}$ \\
\hline Rated power & $5 \mathrm{HP}(3.67 \mathrm{kw})$ \\
\hline Speed & $1500 \mathrm{rpm}$ \\
\hline Injection timing & $24 \mathrm{BTDC}$ \\
\hline Injection pressure & $190 \mathrm{BAR}$ \\
\hline Swept volume & $553 \mathrm{cc}$ \\
\hline Clearance volume & $36.87 \mathrm{cc}$ \\
\hline
\end{tabular}

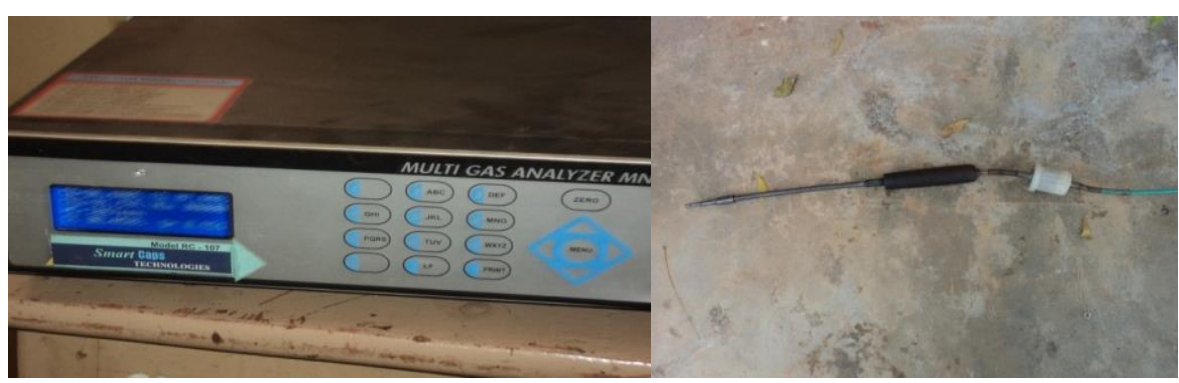

Figure 2. Gas analyzer and Probe of Gas Analyzer

Table 4. Gas Analyzer Specifications

\begin{tabular}{|l|l|}
\hline Principle & NDIR (Non Dispersive Infrared based technology) \\
\hline Gas measured & $\mathrm{CO}, \mathrm{CO} 2, \mathrm{HC}, \mathrm{O} 2$ and NOx (electrochemical sensor) \\
\hline Measuring range & $\begin{array}{l}\mathrm{CO}(0-15 \% \text { vol }), \mathrm{CO} 2(0-20 \% \text { vol }), \mathrm{HC}(0-30000 \mathrm{ppm} \text { vol }), \\
\mathrm{O} 2(0-25 \% \mathrm{vol}), \mathrm{NOx}(0-5000 \mathrm{ppm})\end{array}$ \\
\hline Resolution & $\begin{array}{l}\mathrm{CO}(0.01 \%), \mathrm{CO} 2(0.1 \%), \mathrm{HC}(1 \mathrm{ppm}), \mathrm{O} 2(0.01 \%), \mathrm{NOx}( \\
1 \mathrm{ppm})\end{array}$ \\
\hline Gas flow rate & $1000 \mathrm{ml} / \mathrm{min}$ \\
\hline
\end{tabular}




\begin{tabular}{|l|l|}
\hline Response time & Less than 15 seconds \\
\hline Warm up time & 2 minutes \\
\hline Zero calibration & Every 25 minutes \\
\hline
\end{tabular}

\section{Results and Discussion}

Performance and emission characteristics of ethoxy ethanol and ethylene glycol.

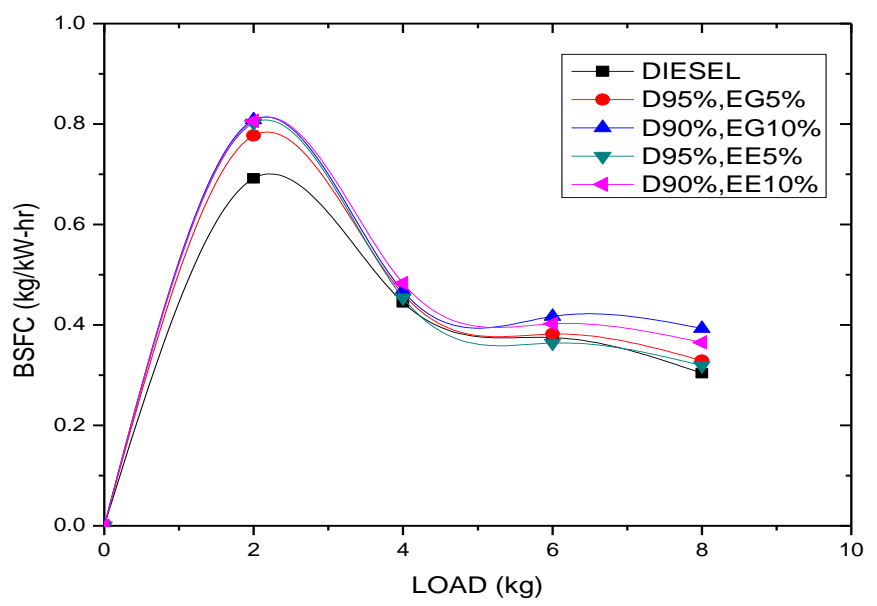

Figure 3. Load VS Specific Fuel Consumption

Figure 3 shows the variation of SFC with load for diesel and oxygenated blends. As seen SFC of the diesel is least, the 10\% EG has the highest SFC as compared with other oxygenated blends. This shows that SFC increases with increase in oxygenated blends. (4)This is mainly due to lower heating value of $10 \% \mathrm{EG}$ blend as compared to diesel fuel. The lower brake power combined with higher fuel consumption causes increased brake specific fuel consumption in the use of EG and EE blends.

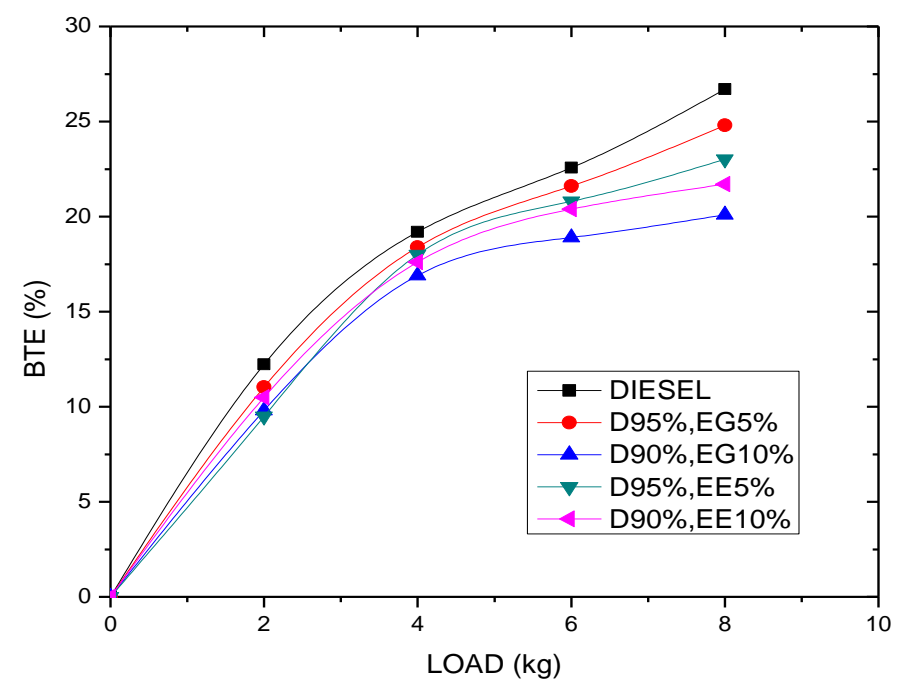

Figure 4. Load vs. Brake Thermal Efficiency 
Figure 4 shows the comparison of brake thermal efficiency with respect to load for diesel and oxygenated blends. It can be seen that diesel has the highest brake thermal efficiency as compared to others. ${ }^{(1)}$ It also shows that $10 \% \mathrm{EG}$ has the least brake thermal efficiency as compared to other oxygenated blends due to lower calorific value and density difference of the blends

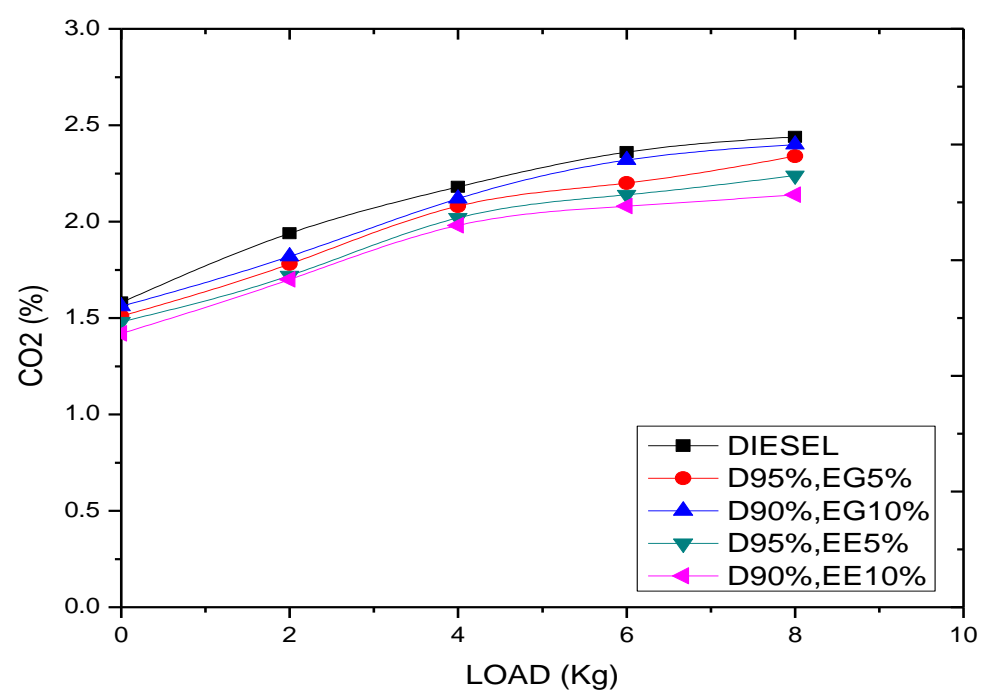

Figure 5. Load VS $\mathrm{CO}_{2}$

Figure 5 shows the $\mathrm{CO}_{2}$ emissions plotted against the different loads. As seen from this figure emissions of $\mathrm{CO}_{2}$ decrease with oxygenated blends. As the load is increased the emission of $\mathrm{CO}_{2}$ also increases for oxygenated blends. This reveals that $\mathrm{CO}_{2}$ emissions decrease as the oxygen content increase. This may be due to better combustion of the blended fuel. The presence of oxygen better assisted in combustion.

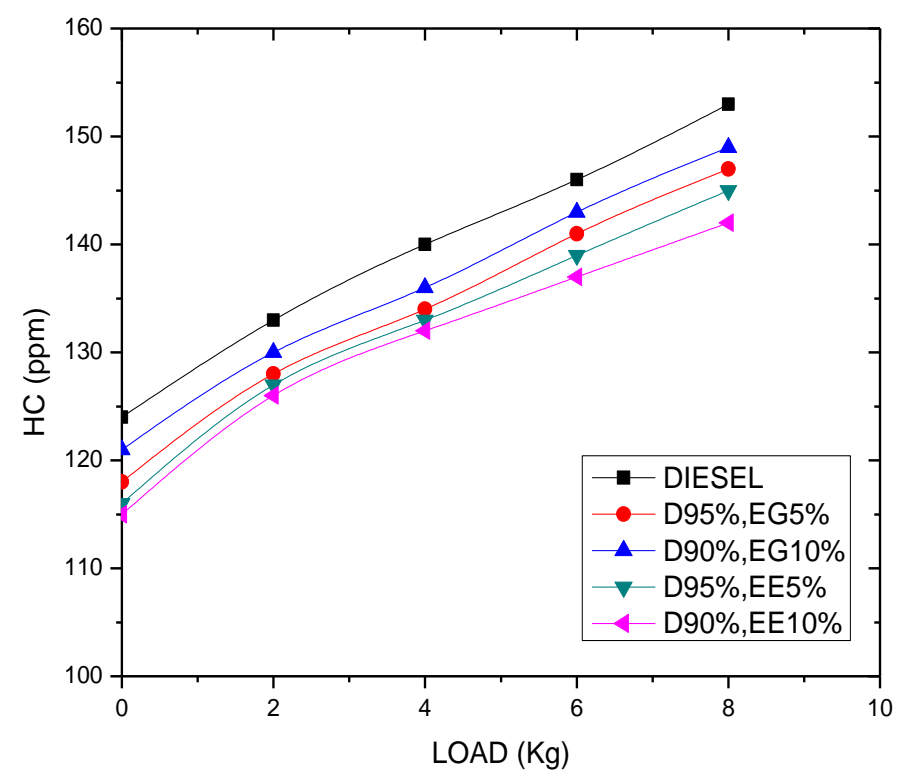

Figure 6. Load Vs HC 
Figure 6 shows the comparison of $\mathrm{HC}$ emissions with respect to load. As seen above the emissions of $\mathrm{HC}$ reduces with using the oxygenated blends. As the load increases there is appreciable increase in $\mathrm{HC}$ emissions of diesel fuel. 10\%EE shows least $\mathrm{HC}$ emissions while the diesel shows higher emission values. This reveals that $\mathrm{HC}$ emissions tend to decrease as the oxygen content increases.

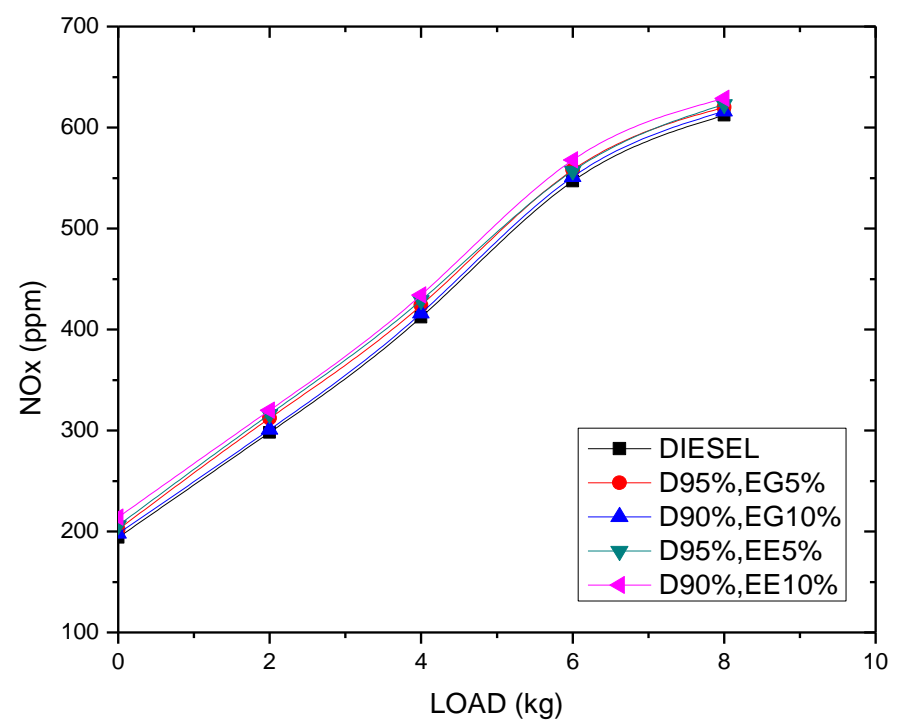

Figure 7. Load Vs $\mathrm{NO}_{x}$

Figure 7 shows the variation of $\mathrm{NO}_{\mathrm{x}}$ with load for diesel and oxygenated blends. All the oxygenated blends increase $\mathrm{NO}_{\mathrm{x}}$ emissions compared to diesel fuel. As the load increases the emissions for the oxygenated blends increase. The more the oxygen content better the combustion and peak temperature is high which results in increased $\mathrm{NO}_{\mathrm{x}}$ emission. ${ }^{(1)}$ The oxygen content and higher cetane number of oxygenated fuel is the reason for increase of the $\mathrm{NO}_{\mathrm{x}}$ emission.

\section{Conclusion}

Diesel combustion and emissions with two kinds of oxygenates having suitable ignitability were investigated over a wide range of blend ratios.

The results may be summarized as follows:

- By addition of oxygenate to ordinary diesel fuel, significant improvements were simultaneously obtained in emissions, SFC, Brake Thermal Efficiency

- Improvements in Brake Thermal Efficiency depended on the content in the fuels and the blended ratios and type of oxygenate.

- The bsfc of oxygenated blends are higher than diesel fuel due to lower heating value as compare to diesel fuel.

- The oxides of nitrogen present in the exhaust gas tend to increase.

- All the Oxygenates are found to be effective in reducing $\mathrm{CO}_{2}$ at all loads.

The limitation with the use of $\mathrm{EE}$ in diesel fuels is cost. If the production efficiency of EE can be made cost competitive with diesel, then EE appears to be a very viable additive in diesel fuel.EE can be made to operate with very low emissions and may help to reduce green house gases like $\mathrm{NO}_{\mathrm{x}}$ and $\mathrm{CO}$ 


\section{References}

[1] G. Devaradjane, "Experimental Investigation on Performance and Emission characteristics of Diesel fuel blended with 2-Ethoxy Ethyle Acetate and 2-Butoxy Ethanol”, SAE Paper no. 2008-01-1681.

[2] R. Zhu, X. Wang, H. Miao, Z. Huang, J. Gao and D. Jiang, "Performance and Emission Characteristics of Diesel Engines Fueled with Diesel Dimethoxymethane (DMM) Blends", Fuel, vol. 87, (2008), pp. 2779-2786.

[3] D. Altiparmak, A. AliKeskin and M. Guru, "Alternative fuel properties of tail oil fatty acid methyl ester -diesel fuel blends", Bioresource Technology, vol. 98, (2007), pp. 241-246.

[4] M. Karabektas, G. Ergen, M. Hosoz, "Effects of the blends containing low ratios of alternative fuels on the performance and emission characteristics of diesel engine", Fuel, (2011).

[5] M. Yoon Kim, S. Hyun Yoon, B. Woo Ryu and C. Sik Lee, "Combustion and emission characteristics of DME as an alternative fuel for compression ignition engines with a high pressure injection system", Fuel, vol. 87, (2008), pp. 2779-2786.

[6] V. Rao Suriseety, A. Kumar Dalai and J. Kozinski, "Alochols as alternative fuels", An overview. Applied Catalysis A: General, vol. 404, (2011), pp. 1-11.

[7] G. Yanfeng, L. Shenghua, G. Hejun, H. Tiegang and Z. Longbao, "A new diesel oxygenate additive and its effects on engine combustion and emissions", Applied Thermal Engineering, vol. 27, (2007), pp. 202-207.

[8] M. Muralidharan, M. Subramanian, P. C. Kanal and R. K. Amphora, "Evaluation of a Novel biofuel blend using diesel-biodiesel-ethanol on light commercial vehicle", SAE2011-28-0015.

\section{Abbreviations}

EG: Ethylene glycol

EE: Ethoxy ethanol

D95\%, EG5\%: Diesel 95\% Ethylene glycol 5\%

D90\%, EG10\%: Diesel 90\% Ethylene glycol 10\%

D95\%, EE5\%: Diesel 95\% Ethoxy ethanol 5\%

D90\%, EE10\%: Diesel 90\% Ethoxy ethanol 10\%

\section{Authors}

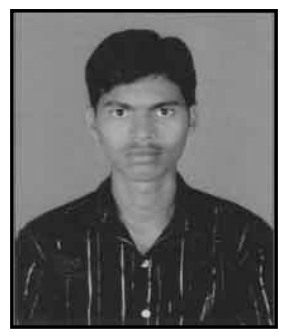

Author name [1]: Sateesh Yalavarthi

Author profile : Master of Engineering in Thermal Engineering from

Hindustan University, Chennai - India.

Designation : Asst. Professor in Mechanical Engineering

Department.

DVR \& Dr.HS MIC College of Technology, Kanchikacherla, Krishna (DT), Andhra Pradesh,

India)

Email ID : sateeshthermal@gmail.com

Author name [2]: Anil Kumar.Chintalapudi

Author profile : Master of Technology in Thermal Engineering. Designation : Asst. Professor in mechanical engineering department.

DVR \& Dr.HS MIC College of Technology,

India)

Kanchikacherla, Krishna (DT), Andhra Pradesh,

Email ID : anilraj_301@yahoo.co.in

Author name [3]: Satya Dev

Author profile : Bachelor of Technology in Mechanical

Engineering. 
International Journal of Advanced Science and Technology Vol.61, (2013) 